\title{
Routine VDRL Test in Pregnant Women: How Justified Is It?
}

\author{
Mosammat Gul-A-Anar, ${ }^{1}$ Tabassum Ghani, ${ }^{2}$ Md. Zahidul Islam, ${ }^{3}$ Mst. Zinat Rehana Shilpi, ${ }^{4}$ Ehsan Ara, ${ }^{5}$ Rehana Parvin, 6 \\ Dina Layla Hossain, ${ }^{7}$ Marshia Ahmed, ${ }^{8}$ Rumnaz Akhanda ${ }^{9}$
}

\section{ABSTRACT}

Background \& objective: The present study was undertaken to justify the role of routine antenatal screening for syphilis using the Venereal Disease Research Laboratory (VDRL) test in Bangladeshi pregnant women.

Methods: The study was carried out in the Department of Gynecology \& Obstetrics Inpatient and Outpatient, Dhaka Medical College Hospital (DMCH) and selected Private Clinics over a period of 6 months between January 2016 to June 2016. Pregnant women attending at the above-mentioned places during the study period were the study population. A total of 371 women attending at antenatal clinic at OPD or admitted in the Inpatient Department of DMCH were consecutively included. The outcome variable was outcome of VDRL test.

Result: In the present study, the mean age of the pregnant women was 24.3 years. In terms of occupation, housewife comprised the main bulk (78.8\%). About $64 \%$ were multigravida and $60 \%$ were primipara. Of the 371 pregnant women subjected to VDRL test, only $4(1.1 \%)$ exhibited reactive. About one-third of the women had history of past abortion. Of them two-thirds had experienced abortion once. Of the aborted cases $57 \%$ were spontaneous and $43 \%$ induced. Ten percent of the women gave the history of delivering dead baby. Three-quarters of the dead babies were fresh, $22.2 \%$ had skin lesion and only one was macerated. Half of the women had history of vaginal discharge, $27.2 \%$ itching in vagina and vulva and $17 \%$ dysuria. However, very few husbands had dysuria, pus discharge through urethra or ulcer in the genital region. About $10 \%$ of women gave the history opthalmia neonatrum in their children born in the past. History of dysuria was rare $(0.8 \%)$, but pus discharged from urethra of their husbands was $12.1 \%$. HbsAg was found positive in $5(1.3 \%)$ cases and pus-cell in urine in $41(11.1 \%)$ cases.

Conclusion: The study concluded that pregnant women with VDRL test positivity in Bangladeshi population are low and, as such, the role of routine antenatal screening for syphilis with VDRL test should be re-considered.

Key words: Routine VDRL, Pregnant women etc.

\section{Authors' information:}

'Dr. Mosammat Gul-A-Anar, Senior Consultant, Obstetrics and Gynaecology, Government Employees Hospital, Fulbaria, Dhaka

${ }^{2}$ Dr. Tabassum Ghani, Associate Professor, Obstetrics and Gynaecology, Dhaka Medical College, Dhaka

${ }^{3}$ Dr. Md. Zahidul Islam, Assistant Professor, Anaesthesia, National Institute of Diseases of Chest \& Hospital

${ }^{4}$ Dr. Mst. Zinat Rehana Shilpi, Assistant Professor, Institute of Child and Maternal Health, Matuail, Dhaka

${ }^{5}$ Dr. Ehsan Ara, Senior Consultant, Obstetrics and Gynaecology, Sadar Hospital, Satkhira

${ }^{6}$ Dr. Rehana Parvin, Assistant Professor, Sheikh Hasina Medical College, Tangail

${ }^{7}$ Dr. Dina Layla Hossain, Junior consultant (Obs \& Gynae), Feto Maternal Medicine Trainee, DMCH

${ }^{8}$ Dr. Marshia Ahmed, Assistant Surgeon, Union Sub-Center, Singasolpur, Narail

${ }^{9}$ Dr. Rumnaz Akhanda, Medical Officer, National Institute of Mental Health, Dhaka

Correspondence: Dr. Mosammat Gul-A-Anar, Phone: +880 1718737693, E-mail: anargul17344@gmail.com 


\section{INTRODUCTION:}

Syphilis is a sexually transmitted disease (STD) caused by Treponema pallidum. Treponema pallidum, an obligatory parasite of man and found in lesions of syphilis, is an extremely delicate spiral organisms with axial filament having 3-4 fibrils possessing characteristic motility. ${ }^{1}$ The Venereal Disease Research Laboratory (VDRL) is a blood test that is used to determine whether a person has an active syphilis. The VDRL test, a slide microflocculation test for syphilis, use an antigen containing cardiolipin, lecithin, and cholesterol. ${ }^{2,3}$ It is a fast, easy to perform test that measures IgM and IgG antibodies to lipoidal material released from damaged host cells as well as to lipoprotein-like material, and possibly cardiolipin released from the Treponemas. ${ }^{4,5}$ The antilipoidal antibodies are antibodies that are not only produced as a consequence of syphilis and other treponemal diseases, but may also be produced in response to non-treponemal diseases of an acute and chronic nature in which tissue damage occurs. ${ }^{6}$ Without some other evidence for the diagnosis of syphilis, a reactive non-treponemal test does not confirm $T$. pallidum infection. Although a positive test usually means that the individual has syphilis, the fact that VDRL looks for antibodies to a non-syphilis specific protein called cardiolipin may lead to false positive result $(1-2 \%)$ as well, which can be caused by many conditions including pregnancy, HIV infection, tuberculosis and some other bacterial infection. ${ }^{7}$

The American Academy of Pediatrics and the American College of Obstetricians and Gynecologists recommend that all pregnant women be screened for syphilis with serologic testing at the first prenatal visit, after exposure to an infected partner and at the time of delivery. ${ }^{8} \mathrm{~A}$ group of researchers from departments of Clinical Microbiology, Christian Medical Collage Hospital, Velour, Tamil Nadu, India did an audit on "The management of pregnant women with positive VDRL tests". Their work shows that only less than $1 \%$ pregnant women were positive for VDRL test. Of the sera positive women only one-third have had foetal loss. ${ }^{9}$ The US preventive services task force (USPSTF) has done "screening for syphilis infection" and strongly recommended that clinicians should screen persons at increased risk for syphilis infection. As screening may result in potential harms (such as clinical evaluation of false- positive results, unnecessary anxiety to the patient and harms of antibiotic use), the USPSTF recommends against routine screening of asymptomatic persons who are not at increased risk for syphilis infections. ${ }^{10}$

In Bangladesh, different studies conducted during 1994 to 2001 on prevalence of sexually transmitted infections (STIs) among urban and rural female populations. While most of the studies were clinic-based, there are few community-based studies. The cumulative data from all these studies showed that the prevalence of $N$. gonorrhoea and C. trachomatis is $0.2-2.4 \%$ respectively and the prevalence of syphilis is $0.7-3 \%$. In pregnant women from urban Dhaka $(n=281)$, prevalence of syphilis was $3 \%$. Among females of moderate risk groups, the prevalence of syphilis was $1.5-3 \% .{ }^{10}$

Syphilis screening and treatment in the antenatal care is an effective way to reduce fetal or infant mortality and morbidity. Therefore, the practice of universal antenatal screening for syphilis has been advised. However, its routine use has been questioned in many societies, particularly in conservative society like Bangladesh, because of extremely low prevalence of syphilis. ${ }^{11}$ The present study was designed to generate information that may help Obstetricians to decide whether routine VDRL test is justified in Bangladeshi pregnant woman seeking antenatal care.

\section{METHODS:}

This Cross-sectional study was carried out on pregnant women in the Department of Gynecology \& Obstetrics Inpatient and Outpatient, Dhaka Medical College Hospital and in the selected Private Clinics over a period 6 months between January 2016 to June 2016. Having obtained 
ethical clearance from the Ethical Committee and verbal consent from the patients, the data collection was commenced. Pregnant women irrespective of age, parity and duration of pregnancy, having report of VDRL test at any registered diagnostic center/clinics carried out during this pregnancy and were willing to repeat VDRL test if requested were included. However, very sick pregnant women admitted in hospital ward for treatment of any other conditions or unable to show the needed reports on the day of interview were excluded. A total of 371 patients were selected. The key variables of interest were history suggestive of possible STI, history strongly suggestive of STI, outcome of VDRL test and outcome of baby of VDRL positive mother. Data processing and analysis were done using SPSS (statistical package for social sciences), version 16. The test statistics used to analyze the data were descriptive statistics. The categorical data were presented as frequency and corresponding percentages, while the continuous data were presented as mean, standard deviation from the mean and range.

\section{RESULTS:}

Age distribution shows that $27.8 \%$ were $<20$ years, $57.1 \%$ were $20-30$ years and $25.1 \% 30$ or $>30$ years with mean age of the patients being 24.3 years. In terms of occupation, housewife comprised the main bulk (78.8\%). Over one-quarter (27\%) was secondary level educated, $21.8 \%$ primary level, $19.4 \%$ SSC, $15.4 \%$ graduate and $9.4 \%$ HSC level educated. Muslim was predominant (94.6\%). Average monthly income was Taka 9774 (Table I).

Over half $(51.8 \%)$ of the husbands were $<30$ years old, $33.7 \%$ were $30-40$ years and $12.9 \%$ 40-50 years old with mean age of the husbands being 31.8 years. They were predominantly Muslim (94.1\%). Service was the prime occupation $(45.6 \%)$, followed by business (32.9\%) \& labour (7\%). Secondary, SSC and HSC level educated each comprised $20 \%$. The average monthly income was Taka 20432 (Table II).

\begin{tabular}{|c|c|c|c|}
\hline $\begin{array}{l}\text { Demographic } \\
\text { features }\end{array}$ & Frequency & Percentage & $\begin{array}{l}\text { Mean } \pm \text { SD } \\
\text { (Range) }\end{array}$ \\
\hline \multicolumn{4}{|l|}{ Age $^{*}$ (years) } \\
\hline$<20$ & 103 & 27.8 & $24.3 \pm 4.6(17-40)$ \\
\hline $20-30$ & 212 & 57.1 & - \\
\hline$\geq 30$ & 56 & 15.1 & - \\
\hline \multicolumn{4}{|l|}{ Occupation } \\
\hline Housewife & 292 & 78.8 & - \\
\hline Student & 12 & 3.2 & - \\
\hline Service & 12 & 3.2 & - \\
\hline Others & 55 & 14.8 & - \\
\hline \multicolumn{4}{|l|}{ Education } \\
\hline Illiterate & 26 & 7.0 & - \\
\hline Primary & 81 & 21.8 & - \\
\hline Secondary & 100 & 27.0 & - \\
\hline SSC & 72 & 19.4 & - \\
\hline $\mathrm{HSC}$ & 35 & 9.4 & - \\
\hline Graduate & 57 & 15.4 & - \\
\hline Income (Tk.) & - & - & $9774.2 \pm 6596.5$ \\
\hline \multicolumn{4}{|l|}{ Religion } \\
\hline Muslim & 351 & 94.6 & - \\
\hline Hindu & 20 & 5.4 & - \\
\hline
\end{tabular}

Table II. Distribution of respondents by demographic features of their husband $(n=371)$

\begin{tabular}{|c|c|c|c|}
\hline $\begin{array}{l}\text { Particulars of } \\
\text { husband }\end{array}$ & Frequency & Percentage & $\begin{array}{c}\text { Mean } \pm \text { SD } \\
\text { (Range) }\end{array}$ \\
\hline Age (years) & & & $(31.8 \pm 5.9)(20-60)$ \\
\hline$<30$ & 192 & 51.8 & - \\
\hline $30-40$ & 125 & 33.7 & - \\
\hline $40-50$ & 48 & 12.9 & - \\
\hline$\geq 50$ & 6 & 1.6 & - \\
\hline \multicolumn{4}{|l|}{ Occupation } \\
\hline Service & 169 & 45.6 & - \\
\hline Business & 122 & 32.9 & - \\
\hline Labour & 26 & 7.0 & - \\
\hline Others & 54 & 14.3 & - \\
\hline \multicolumn{4}{|l|}{ Education } \\
\hline Illiterate & 21 & 5.7 & - \\
\hline Primary & 51 & 13.7 & - \\
\hline Secondary & 72 & 19.4 & - \\
\hline SSC & 73 & 19.7 & - \\
\hline HSC & 67 & 18.1 & - \\
\hline Graduate & 87 & 23.5 & - \\
\hline Income (Tk.) & - & - & $20432.8 \pm 1924.9$ \\
\hline \multicolumn{4}{|l|}{ Religion } \\
\hline Muslim & 349 & 94.1 & - \\
\hline Hindu & 22 & 5.9 & - \\
\hline
\end{tabular}


About $64 \%$ of the respondents were multigravida and $36 \%$ primigravida. In terms of parity $59.5 \%$ were primipara and $40.5 \%$ multipara (Table III). About one-third $(31.5 \%)$ of the women had history of past abortion. Of them two-thirds $(67.6 \%)$ experienced abortion once, $24.4 \%$ twice and $7.7 \% 3$ times. Of the aborted cases, $57.1 \%$ had spontaneous abortion and $42.9 \%$ had induced abortion. Duration of gestation in $1^{\text {st }}$ abortion was about 12 weeks. Thirteen percent developed complications. Sixty percent of the $2^{\text {nd }}$ abortion was spontaneous with average duration of gestation being 10.6 weeks. The data of $3^{\text {rd }}$ abortion are illustrated in Table III.

\begin{tabular}{|c|c|c|c|}
\hline $\begin{array}{l}\text { Table III. Distribution of respon } \\
\text { abortion history }(\mathbf{n}=\mathbf{3 7 1})\end{array}$ & ndents & by pregnancs & profile \& \\
\hline $\begin{array}{l}\text { Pregnancy profile } \\
\& \text { abortion history }\end{array}$ & equency & Percentage & $\begin{array}{l}\text { Mean } \pm \text { SD } \\
\text { (Range) }\end{array}$ \\
\hline Gravida \& parity & & & \\
\hline Gravida & & & \\
\hline Primigravida & 134 & 36.1 & - \\
\hline Multigravida & 237 & 63.9 & - \\
\hline Parity & & & \\
\hline Primipara & 221 & 59.5 & - \\
\hline Multipara & 150 & 40.5 & - \\
\hline Abortion history & & & \\
\hline Past abortion & 117 & 31.5 & - \\
\hline How many abortion $(n=117)$ & & & \\
\hline 1 times & 79 & 67.6 & - \\
\hline 2 times & 29 & 24.7 & - \\
\hline 3 times & 9 & 7.7 & - \\
\hline Duration of gestation $1^{\text {st }}$ abortion & on - & - & $11.9 \pm 6.8$ \\
\hline Nature of $1^{\text {st }}$ abortion & & & \\
\hline Spontaneous & 64 & 57.1 & - \\
\hline Induced & 48 & 42.9 & - \\
\hline Health complication $1^{\text {st }}$ abortion & 14 & 13.2 & - \\
\hline Duration of gestation $2^{\text {nd }}$ abortion & ion - & - & $10.6 \pm 6.9$ \\
\hline Nature $2^{\text {nd }}$ abortion & & & \\
\hline Spontaneous & 20 & 60.6 & - \\
\hline Induce & 13 & 39.4 & - \\
\hline Health complication $2^{\text {nd }}$ abortion & n 3 & 9.1 & - \\
\hline Duration of gestation $3^{\text {rd }}$ abortion & on - & - & $14.8 \pm 5.2$ \\
\hline Nature $3^{\text {rd }}$ abortion & & & \\
\hline Spontaneous & 4 & 80.0 & - \\
\hline Induce & 1 & 20.0 & - \\
\hline Health complication $3^{\text {rd }}$ abortion & n 1 & 20.0 & - \\
\hline
\end{tabular}

\begin{tabular}{|c|c|c|c|}
\hline $\begin{array}{l}\text { History of } \\
\text { dead baby }\end{array}$ & Frequency & Percentage & $\begin{array}{c}\text { Mean } \pm \text { SD } \\
\text { (Range) }\end{array}$ \\
\hline Still born & 36 & 9.7 & - \\
\hline \multicolumn{3}{|l|}{ Duration of gestation (weeks) } & $31.3 \pm 13.4$ \\
\hline Maternal health complication & on 5 & 13.9 & - \\
\hline \multicolumn{4}{|l|}{ Types $(n=36)$} \\
\hline Fresh & 27 & 75.0 & - \\
\hline Skin lesion & 8 & 22.2 & - \\
\hline Macerated & 1 & 2.8 & - \\
\hline \multicolumn{4}{|l|}{ Sex } \\
\hline Male & 18 & 50.0 & - \\
\hline Female & 18 & 50.0 & - \\
\hline \multicolumn{4}{|l|}{ Place of delivery } \\
\hline Home & 12 & 33.3 & - \\
\hline Hospital & 24 & 66.7 & - \\
\hline
\end{tabular}

Table V. Distribution of respondents by complications of wife \& husband $(n=371 *)$

$\begin{array}{lcc}\text { Complications of wife \& husband } & \text { Frequency } & \text { Percentage } \\ \begin{array}{l}\text { Complications of wife } \\ \text { Vaginal discharge }\end{array} & 184 & 49.6 \\ \text { Itching in vagina/vulva } & 101 & 27.2 \\ \quad \text { Dysuria } & 63 & 17.0 \\ \quad \begin{array}{l}\text { Any ulcer in the genital region } \\ \text { Complications of husband }\end{array} & 2 & 0.5 \\ \quad \begin{array}{l}\text { Dysuria } \\ \text { Pus discharge through urethra }\end{array} & 18 & 4.9 \\ \text { Any ulcer in the genital region } & 14 & 3.8 \\ \end{array}$

* Total will not correspond to $100 \%$, for multiple response

\begin{tabular}{l}
$\begin{array}{l}\text { Table VI. Distribution of respondents by their past history of } \\
\text { medical significance }\end{array}$ \\
$\begin{array}{l}\text { past history of } \\
\text { medical significance }\end{array}$ \\
\hline
\end{tabular}

\section{Past history of medical significance}

\section{Opthalmia Neonatorum}

in new-born in past

History of dysuria of husbands

Pus discharged from

urethra of husbands

45

Laboratory tests findings

\section{HbsAg}

$\begin{array}{lcc}\text { Negative } & 366 & 98.7 \\ \text { Positive } & 5 & 1.3 \\ \text { Urine R/E } & & \\ \text { NAD } & 330 & 88.9 \\ \text { Pus cell } & 41 & 11.1\end{array}$




\begin{tabular}{|c|c|c|}
\hline VDRL & Frequency & Percentage \\
\hline Reactive & 4 & 1.1 \\
\hline Non-reactive & 367 & 98.9 \\
\hline
\end{tabular}

About $10 \%$ of the women gave the history of dead baby with average duration of gestation being 31.3 weeks. Of them $13.9 \%$ had maternal complications. Three-quarters of the dead babies were fresh, $22.2 \%$ had skin lesion and only one was macerated. Male and females were equal in number. Two-thirds (66.7\%) of the babies were born in hospital and the rest at home (Table IV). About half (49.6\%) of the women had history of vaginal discharge, $27.2 \%$ itching in vagina and vulva and $17 \%$ dysuria. However, very few husbands had dysuria (4.9\%), pus discharge through urethra $(3.8 \%)$ and any ulcer in the genital region $(2.2 \%$ ) (Table $\mathrm{V}$ ). About $10 \%$ of women gave the history of opthalmia neonatorum in their children born in the past. History of dysuria was rare $(0.8 \%)$, but pus discharged from urethra of their husbands was reported in $12.1 \%$ cases. HbsAg was found positive in $5(1.3 \%)$ cases and pus-cell in urine was found in $41(11.1 \%$ ) cases. (Table VI). Of the 371 cases subjected to VDRL test, only $4(1.1 \%)$ exhibited reactive. However, the babies of VDRL positive mothers did not have any problem (Table VII).

\section{DISCUSSION:}

In the present study out of 371 pregnant women subjected to VDRL test, only $4(1.1 \%)$ exhibited weakly reactive. About one-third of these women had history of past abortion. Of the aborted cases $57 \%$ were spontaneous and $43 \%$ induced. Ten percent of the women gave the history of delivering dead baby. Three-quarters of the dead babies were fresh, $22.2 \%$ had skin lesion and only one was macerated. Half of the women had history of vaginal discharge, $27.2 \%$ itching in vagina and vulva and $17 \%$ dysuria. However, very few of their husbands had dysuria, discharge of pus through urethra and any ulcer in the genital region. About $10 \%$ of women gave the history of opthalmia neonatorum in their children born in the past. History of dysuria was rare $(0.8 \%)$, but pus discharged from urethra of their husbands was reported in $12 \%$ cases. HbsAg was found positive in $5(1.3 \%)$ cases and pus-cell in urine was found in $41(11.1 \%)$ cases.

The values of the VDRL test lies in its low cost and ease of titration. Prevalence of syphilis in pregnant women in developing countries ranges from $3-18 \% .{ }^{12,13}$ The prevalence of VDRL reactive in our study is $1.1 \%$ which does not mean that the prevalence of syphilis is $1.1 \%$. A study performed in Amazon region, Brazil on 712 pregnant women under field conditions in remote communities where fluorescent treponemal antibody absorption (FTA-Abs) test was considered as the 'gold standard' and the VDRL test was done to determine the active syphilis cases. Among women, 2.2\% had syphilis (Positive FTA-Abs) and $0.8 \%$ active syphilis (FTA-Abs and VDRL positive). The sensitivity \& specificity of the test was $62.5 \%$ and $99.1 \%$ (Final Recommendation Statement: Syphilis Infection: Screening, 2014). If we consider that the sensitivity of the test is $62 \%$, than the prevalence of syphilis is assumed to be $0.62 \%$ which is quite comparable with the prevalence of syphilis in a Nigerian study $(0.55 \%)^{14}$ and that in a Maiduguri (Northern Nigeria) study $(0.05 \%)^{13}$ but significantly less than $10 \%$ prevalence reported from Oshogbo (Western Nigeria). ${ }^{15}$ In Enugu (South Eastern Nigeria) screening values of $3.06 \%, 1.3 \%$ and $0.125 \%$ have been reported by successive studies ${ }^{16-18}$ indicating that the prevalence of syphilis is decreasing. While the VDRL test is useful in screening infectious syphilis, it may fail to diagnose the primary disease. However, it is still useful and considered most sensitive in latent syphilis.

Most pregnant women with syphilis are asymptomatic and the disease can only be identified through screening programs. Routine prenatal VDRL test can detect syphilis allowing timely intervention to prevent adverse pregnancy outcomes and neonatal infection with syphilis. ${ }^{19-21}$ Transmission occurs more commonly in the last 
two trimesters, but the spirochete can cross the placenta at any time during pregnancy. ${ }^{22}$ Therefore, fetal death and morbidity due to congenital syphilis are preventable if the infected mother is identified and treated appropriately by the middle of the second trimester.

But in a population with extremely low rate of syphilis, the value of routine testing with VDRL should be reconsidered. Data on syphilis in obstetric population in Saudi Arabia is limited, but in general it is in line with the notion of low prevalence $(0.03-0.85 \%))^{23-25}$ Hamdi \& associates ${ }^{26}$ in another study in Saudi Arabia showed that the relative frequencies for syphilis among domestic expatriate workers (DEWs) screened for pre-employment is $23.8 \%$, more frequent among Indonesian and the Philippines nationals. The findings obtained from the present study supports that the prevalence of syphilis in conservative population like ours is extremely low and routine investigation for syphilis using VDRL test is of little value. It unnecessarily increases burden of the cost and anxiety of the women concerned as well as her families.

\section{CONCLUSION:}

The study concluded that only one in hundred Bangladeshi pregnant women exhibits reactive VDRL test. As the sensitivity of the test is low, the prevalence of syphilis is even low (less than one percent). Therefore, the role of routine antenatal screening for syphilis with VDRL test in Bangladeshi population should be re-considered.

\section{REFERENCES:}

1. US Preventive Service Task Force. Screening Syphilis Infection: Recommendation Statement. Ann Fam Med 2004;2:362-365.

2. Harris A, Rosenberg AA, delVecchio ER. The VDRL slide flocculation test for syphilis: II. A supplementary report. J Vener Dis Inform 1948;29:72-5.

3. Duncan WP, Bossack HN, Harris A. VDRL slide spinal fluid test. Am J Clin Pathol 1961;35:93-5.

4. Matthews HM, Yang TK, Jenkin HM. Unique lipid composition of Treponemapallidum (Nichols virulent strain). Infect Immun 1979;24(713-19).
5. Belisle JT, Brandt ME, Radolf JD, Norgard MV. Fatty acids of Treponemapallidum and Borreliaburgdorferi lipoproteins. J Bacterio/ 1994;176(8):2151-7.doi: 10.1128/ jb.176.8.2151-2157.1994..

6. Catterall RD. Presidential address to the M.S.S.V.D.: Systemic disease and the biological false-positive reaction. Br J Vener Dis 1972;48:1-12.

7. Centers for Disease Control and Preservation. Syphilis tasting algorithms using treponeunal test for Initial spacing four laboratories; New York city, 2005-2006. MMWR weekly 2008;57(32):872-5.

8. American Academy of Pediatrics. American college of obstetrics and gynecologist and March of dimes. Birth affects foundation candlings for parietal case. 615 and elk glycogen village. Americans academy of petulancies 2007.

9. Mathai E, Mathai M, Prakash JA, Bergström S. Audit of management of pregnant women with positive VDRL tests. Natl Med J India 2001;14(4):202-4.

10. National guidelines for management of sexually transmitted infection, 2003, 'epidemiadaguy of STIs \& HIV in Bangladesh', World Health Organization, Jan 1.

11. Olubukola A, Adesina O. Routine antenatal syphilis screening in South west Nigeria-a questionable practice. Ann Ib Postgrad Med 2010;8(1):16-9. doi: 10.4314/aipm.v8i1.63952.

12. Mehmet G, William JL. Syphilis in pregnancy. Sex Transm Inf 2000;76:73-79.

13. Bukar M, Audu BA, Takai UI, Ajayi BB, Kullima AA. Is routine antenatal screening for syphilis in Nigeria still justified clinically and economically? Saudi Med J 2009;30(10):1311-5.

14. Yakasai IA, Umar U, Ibrahim SA, Abubakar IS. Is routine antenatal screening test for syphylis using VDRL still relevant? Academic Research International 2012;2(2): 151-155.

15. Ojo DA, Oyetunji IOA. Seroprevalence of syphilis among pregnant women in Osogbo in Southwestern Nigeria. ASSET Series B 2007;6(1):61-65.

16. Ozumba UC, Oshi DC, Nwokegi CM, Anya SE. Trends in seroreactivity for syphilis among pregnant Nigerian women. Sex Transm Inf 1999;75:120-123.

17. Ikeme AC, Okeke TC. The prevalence of VDRL as routine test for pregnant women: a critical study. Niger J Clin Pract 2006;9:65-7.

18. Taiwo SS, Adesiyi YO, Adekanle DA. Screening for syphilis during pregnancy in Nigeria: a practice that must continue. Sex Transm Infec 2007;83:357-9. 
19. Saloojee H, Velaphi S, Goga Y, Afadapa N, Steen R, Lincetto $O$. The prevention and management of congenital syphilis: an overview and recommendations. Bull World Health Organ 2004;82(6):424-430.

20. Hira SK, Bhat GJ, Chikamata DM, Nkowane B, Tembo G, Perine $\mathrm{PL}$, MeheusA. Syphilis intervention in pregnancy: Zambian demonstration project. Genitourin Med 1990; 66(3):159-164

21. Watson-Jones D, Gumodoka B, Weiss H, Changalucha J, Todd J, Mugeye K, BuvéAv. Syphilis in pregnancy in Tanzania. II. The effectiveness of antenatal syphilis screening andsingle-dose benzathine penicillin treatment for the prevention of adverse pregnancyoutcomes. $J$ Infect Dis 2002;186(7):948-957.

22. Berman SM. Maternal syphilis: pathophysiology and treatment. Bull World Health Organ 2004;82(6): 433-438.
23. Lumbiganon $P$, Piaggio $G$, Villar J, Pinol A, Bakketeig L, Bergsjo $\mathrm{P}$ et al. WHO Antenatal Care Trial Research Group, The epidemiology of syphilis in pregnancy. Int J STD AIDS 2002;13(7):486-494.

24. Madani TA. Sexually transmitted infections in Saudi Arabia. BMC Infect Dis 2006;6:3.

25. Shakoor Z. Antenatal screening for syphilis at a tertiary care hospital in Riyadh. Ann Saudi Med 2004;24(4): 262-264.

26. Hamdi SA, Ibrahim MA. Sexually transmitted diseases in domestic expatriate workers in Jeddah Saudi Arabia. Ann Saudi Med 1997;17(1):29-31. 